\title{
The Impact of Gender on Entrepreneurial Intention in a Peripheral Region of Europe: A Multigroup Analysis
}

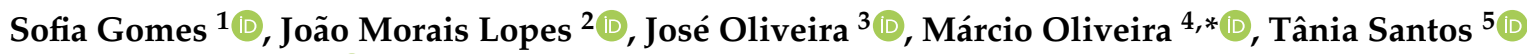 \\ and Marlene Sousa ${ }^{5}$ (D) \\ 1 REMIT-Research on Economics, Management and Information Technologies, University Portucalense, \\ R. Dr. António Bernardino de Almeida 541, 4200-072 Porto, Portugal; sofiag@upt.pt \\ 2 NECE-Research Unit in Business Sciences, Miguel Torga Institute of Higher Education, University of Beira \\ Interior, Largo Cruz de Celas nº1, 3000-132 Coimbra, Portugal; joao.lopes.1987@hotmail.com \\ 3 ISPGAYA, Av. dos Descobrimentos 333, 4400-103 Vila Nova de Gaia, Portugal; jcastroliveira@gmail.com \\ 4 NECE-Research Unit in Business Sciences, Polytechnic Institute of Leiria, Rua General Norton de Matos, \\ Apartado 4133, 2411-901 Leiria, Portugal \\ 5 CICS.NOVA - Interdisciplinary Center of Social Sciences, Polytechnic Institute of Leiria, Rua General Norton \\ de Matos, Apartado 4133, 2411-901 Leiria, Portugal; tania.santos@ipleiria.pt (T.S.); \\ marlene.sousa@ipleiria.pt (M.S.) \\ * Correspondence: marcio.oliveira@ipleiria.pt
}

\section{check for} updates

Citation: Gomes, Sofia, João Morais Lopes, José Oliveira, Márcio Oliveira, Tânia Santos, and Marlene Sousa. 2021. The Impact of Gender on Entrepreneurial Intention in a Peripheral Region of Europe: A Multigroup Analysis. Social Sciences 10: 415. https://doi.org/10.3390/ socsci10110415

Academic Editors: Carlos Teixeira and Nigel Parton

Received: 20 September 2021

Accepted: 27 October 2021

Published: 29 October 2021

Publisher's Note: MDPI stays neutral with regard to jurisdictional claims in published maps and institutional affiliations.

Copyright: (C) 2021 by the authors Licensee MDPI, Basel, Switzerland. This article is an open access article distributed under the terms and conditions of the Creative Commons Attribution (CC BY) license (https:/ / creativecommons.org/licenses/by/ $4.0 /)$.

\begin{abstract}
The last two decades were characterized by an increase in attention on entrepreneurship. An emerging trend in the literature is associated with the different contributions that genders may have regarding entrepreneurship and entrepreneurial intentions. This paper assesses gender impact on entrepreneurial intention in a peripheral region of Europe. The methodology used is quantitative and based on a sample of 1114 observations. The obtained results suggest that women's perceived behavioral control does not have a less direct positive impact on entrepreneurial intention when compared to men's. Women's personal attitude has a less direct positive impact on entrepreneurial intention when compared to men's, as social norms, on the one hand, have a less direct positive impact on women's personal attitude when compared to men's, and, on the other hand, have a less direct positive impact on women's perceived behavioral control when compared to men's. Finally, it was also verified that social norms have a less positive indirect impact through personal attitude and perceived behavioral control on women's entrepreneurial intention when compared to men's. These findings contribute to enlighten the literature by strengthening the theoretical framework on women's entrepreneurial intention in peripheral regions. Regarding practical contributions, suggestions are addressed to public decision makers, universities, and civil society, to adopt practices to increase entrepreneurship in women. This research is original because it is the first to perform this study in Portugal, a peripheral region of Europe.
\end{abstract}

Keywords: entrepreneurship; gender; entrepreneurial intention; theory of planned behavior; multigroup analysis; preferences; peripheral region

\section{Introduction}

Entrepreneurship is widely recognized by all regional actors (government, academia, and industry) as a leading driver of the socio-economic development of countries and their regions; consequently, its promotion has been growing (Lopes et al. 2018; Maes et al. 2014; and Molino et al. 2018). Entrepreneurship is strongly affected by innovation; it is essential that regions, through their policymakers, invest in technology and improve economic structures, which, in turn, causes employment to grow and increases the wealth created by these economies (Mei et al. 2016; Gurel et al. 2010; Nabi and Holden 2008; and Gomes et al. 2021).

In this context, for the last two decades, the interest of researchers to study entrepreneurship has been growing (Lopes et al. 2021a). This growth was accompanied 
by successive incentives given by regional policymakers that aim to increase productivity and economic growth, as well as social development (Denanyoh et al. 2015; and Campos et al. 2017). Therefore, entrepreneurial intention is a relevant subject of study, as it defines the intention that individuals have to initiate their business (Lopes et al. 2020b; Yildırım et al. 2016; and Atitsogbe et al. 2019).

Concerning entrepreneurial potential, the creation of a company significantly contributes to satisfaction and personal fulfillment. Thus, entrepreneurs should have a propensity for risk as well as creativity (Urbano et al. 2019; and Linan et al. 2013). Nevertheless, there are motives behind the unfulfillment of entrepreneurial intentions, that is, for why companies are not incorporated and are not going to the market (Yan et al. 2018; and Badri and Hachicha 2019). Therefore, scholars have been making efforts to strengthen and identify the factors that foster and increase entrepreneurship (Fayolle and Liñán 2014; Ahsan and Fernhaber 2019; Martínez-González et al. 2019; and Lopes et al. 2020a).

Entrepreneurship can be affected by environmental factors, which, usually, influence the process of creating a business the most; amongst these factors, we can mention the access that entrepreneurs have to financial resources, culture, or education (Audretsch et al. 2012, 2017; and Lanahan and Feldman 2015). Innovation is a major factor in entrepreneurship and it is dependent of and subject to influences by the institutional context of the adjacent environment (Alvedalen and Boschma 2017; and Stam 2015). As far as the institutional context is concerned, it is constituted by regulatory and normative institutions. Normative institutions are composed of social expectations and obligations, such as values and norms. Regulatory institutions are concerned with formal laws and rules (Scott 2008; and MartínezGonzález et al. 2019).

In addition to environmental factors, personal factors are also important for entrepreneurship. Thus, the perceptions of the entrepreneur's attributes, such as motivation, self-efficacy, and values, influence whether a company is created or not (Abdullah et al. 2018; Afshar Jahanshahi et al. 2018; and Fuller et al. 2018). Nonetheless, concerning the attributes of the entrepreneur, the entrepreneurial intention is the one that is pointed out in the literature as having the most importance. It can be said that entrepreneurial intention is the variable that best envisages the behavior of the potential entrepreneur (Martínez-González et al. 2019; Trettin and Welter 2011; and Lee and Wong 2004).

In recent decades, theoretical models based on the intention of the entrepreneur's behavior have emerged (Hindle et al. 2009; Krueger et al. 2000; and Schlaegel and Koenig 2014). Amongst these models, the one from Ajzen (1985) can be emphasized. This model is based on the theory of planned behavior (TPB), which is premised on predicting, understanding, and altering human social behavior (Ajzen 1991, 2012; Krueger and Brazeal 1994; Krueger 2020; and Vamvaka et al. 2020).

The theory of planned behavior (TPB) determines that the forerunner of voluntary and premeditated behavior is the intention of an individual to participate in the behavior. In turn, the intention concerns the subjective norms, attitudes of the person, and also the perceived behavioral control (PBC). As a rule, the TPB also stresses that, the more the $\mathrm{PBC}$ is favorable to the subjective norm and attitude, the greater the probability of an individual's intention to accomplish the behavior (Vamvaka et al. 2020). That said, when an individual has enough control over his/her behavior, the individual is likely to perform his/her intentions as soon as he/she has an opportunity (Ajzen 1991, 2020). Consequently, the literature suggests that entrepreneurial intention, attitude, and PBC should be treated and considered as multidimensional constructs (Vamvaka et al. 2020; Schlaegel and Koenig 2014; and Thompson 2009).

In recent literature on entrepreneurship and entrepreneurial intention, one of the trends is related to the function of gender in the development of entrepreneurial intentions (Vamvaka et al. 2020; Shinnar et al. 2012; Shirokova et al. 2016; Zampetakis et al. 2017; and Zhao et al. 2005). Conscious of the importance of entrepreneurship, governments, as well as academia, are being progressively stirred to analyze the aspects that stimulate entrepreneurial intentions (Lopes et al. 2018; Maes et al. 2014; and Borges et al. 2021). Thus, 
governments and academia have to pay special attention to women's entrepreneurial intentions, as they have specific characteristics (Adamus et al. 2021). Consequently, the analysis of the entrepreneurial intention across the board may not be suitable (Salavou et al. 2021; and Westhead and Solesvik 2016). Nowadays, women are increasingly adopting an important role in entrepreneurship, despite their contributions being lower than those by men (Rubio-Bañón and Esteban-Lloret 2016; and Vracheva and Stoyneva 2020). Moreover, we are witnessing a vigorous promotion by the European Commission on the importance of entrepreneurship throughout the different member states. Female entrepreneurship is emerging as a high-priority topic, as demonstrated in several European Union reports (Salavou et al. 2021; and Miranda et al. 2017).

The literature on entrepreneurship has identified that this is not an exclusively economic phenomenon. Entrepreneurship is also considered a cultural phenomenon; consequently, not all results can be generalized outside the context of their respective study (Adamus et al. 2021; Borges et al. 2021; Gomes et al. 2021; and Lopes et al. 2021b). According to Adamus et al. (2021), economies that have working women are less likely to face economic downturns, that is, families with a working mother are less likely to experience poverty. Thus, it is important to study entrepreneurial intention from a gender perspective, with a significant sample in other contexts to generalize the results (Vamvaka et al. 2020; Mei et al. 2016; Atitsogbe et al. 2019; Maes et al. 2014; and Borges et al. 2021) in similar cultural regions. That said, the main objective of this research is to assess the impact of gender on entrepreneurial intention in a peripheral region of Europe. The methodology used is quantitative and based on a sample of 1114 observations, located in Portugal, a peripheral region of Europe.

The study of peripheral regions is relevant when considering the GDP per capita, as, economically, these regions are considered to be less developed. Generally, these regions have low levels of science and education, which translate into a low level of human capital. This leads to low incomes among the population and a limited amount of local policymakers. Peripheral regions have a low level of infrastructure as well as limited availability of territorial resources (IT and communications) when compared to more developed countries (Lewandowska et al. 2021; and Lopes et al. 2020b).

Based on Worldometer data, Portugal has 10,158,654 inhabitants on 13 October 2021, which corresponds to $0.13 \%$ of the world population and $1.36 \%$ of the total population of the European Union. About $67 \%$ of the population is urban, which corresponds to $6,775,807$ inhabitants. Portugal is located on the periphery of Europe and has an area of $91,590 \mathrm{~km}^{2}$ (Worldometer 2021).

This research is ordered as follows. The first Section introduced the subject and problem under study. In Section 2, an extensive review of the available literature on entrepreneurial intentions and TPB is performed, as well as the formulation of the hypotheses. In Section 3, the methodology and data collection are described. In Section 4, the results are exhibited, discussed, and compared against the current literature. In Section 5, the conclusions are disclosed, revealing the most significant findings and contributions to theory and practice as well as suggestions for forthcoming investigations.

\section{Literature Review}

\subsection{Theory of Planned Behaviour and Entrepreneurial Intentions}

Intention can be understood as a mindful, deliberate, and premeditated mental state that takes place before action and consents to the straight consideration to certain types of behaviors, such as the creation of a business (Esfandiar et al. 2019). In the entrepreneurship framework, entrepreneurial intention can be considered as a "self-recognized conviction" by any individual willing to start a new business venture, thus becoming a crucial element to understand the procedure of forming a new business (Farrukh et al. 2018; Liñán et al. 2011; and Ridha et al. 2017). Entrepreneurial intention can also be understood as a status of mind that leads an individual to choose his/her job instead of working for other people (Karimi et al. 2016; and Lopes et al. 2021b). 
The TPB is an intention/behavior model that has been extensively used in entrepreneurship investigation, whereby the effectiveness and capability to envisage entrepreneurial intention was already demonstrated in several entrepreneurship studies (Karimi et al. 2016). The model by Ajzen (1991) enlightens how the social and cultural environment distresses human behavior. According to this model, the individual's intentions are the result of three determinants: personal attitude, perceived behavioral control, and social norms.

Personal attitude is related to the individual's assessment of a certain behavior or action characterized as being beneficial, indicating a favorable or unfavorable personal assessment of the intention to become an entrepreneur (Ajzen 1991; Enkel and Bader 2016; Krueger and Carsrud 1993; and Liñán et al. 2011). Several studies (Fayolle et al. 2014; Liñán and Chen 2009; Martínez-González et al. 2019; and Ruiz-Rosa et al. 2020) found a positive relationship between personal attitude and the individual's entrepreneurial intention.

The perceived behavioral control characterizes the tendency to perform and the perceived likelihood of exhibiting a particular behavior is explained as the self-efficacy of the individual (Krueger and Carsrud 1993). This is revealed in the greater or lesser difficulty that an individual feels when performing an action, related to the ability to control their behavior (Ruiz-Rosa et al. 2020). It is considered that the self-perception of an individual capacity to perform a certain action will influence significantly the intention to execute such action, which can be translated into a positive relationship between perceived behavioral control and the individual's entrepreneurial intention (Krueger et al. 2000; Liñán and Chen 2009; Ruiz-Rosa et al. 2020; and Smith and Woodworth 2012).

Social norms refer to the community pressure exerted by individuals' opinions about the projected behavior, depending on the anticipation of support from other important people (Krueger and Carsrud 1993; Lortie et al. 2017; and Lortie and Castogiovanni 2015). Furthermore, it refers to the perception that "reference people" may or may not approve of the individual's decision to become an entrepreneur (Ajzen 2002).

Some authors consider it is sensible to assume a positive relationship between this variable and the entrepreneurial intention as they understand that entrepreneurs are affected by comments of people related to their contiguous environment and related to their entrepreneurial intentions (Ruiz-Rosa et al. 2020; and Tiwari et al. 2017). However, some studies did not find a significant relationship between social norms and the entrepreneurial intention of individuals (Autio et al. 2001; Carsrud and Brännback 2011; Krueger et al. 2000; and Liñán and Chen 2009).

\subsection{TPB Factors Mediating the Effect of Gender on Entrepreneurial Intentions}

Numerous studies (Davidsson and Honig 2003; Ferri et al. 2018; Karimi et al. 2013; Krueger et al. 2000; Liñán and Chen 2009; Lortie et al. 2017; Maes et al. 2014; Miranda et al. 2017; Veciana et al. 2005; and Wang and Wong 2004) analyzed entrepreneurial intentions according to gender. Krueger et al. (2000) state that gender roles enhance the understanding of entrepreneurial intentions, applied to the differences between men and women in this context. Moreover, the study of Wang and Wong (2004) concluded that gender, experience, and level of education are significant factors to explain the individuals' entrepreneurial intentions.

Ferri et al. (2018) referred that, in general, women face gender-related obstacles to obtain trustworthiness and resources in the business world. This is not because of lack of skills, but due to reasons associated with their personal and professional life (e.g., breaks for maternity leave, difficulty in obtaining loans, and less capital to invest). Social recognition is also very important to them.

An analysis of the TPB factors in a detailed manner reveals that the study of Karimi et al. (2013) demonstrates that males are driven by instrumental factors (since personal attitude is very important for men), while females are more motivated by social factors (social norms are significant for women). In this study, perceived behavioral control was 
the factor that contributed the most to the prediction of the entrepreneurial intentions of both genders.

As mentioned above, several studies have shown that personal attitude is positively related to entrepreneurial intentions, both in women (Ferri et al. 2018) and men (Karimi et al. 2013). The perceived behavioral control factor also has a positive effect on women's entrepreneurial intentions, as it explains that they will translate their intentions into actions (Ferri et al. 2018). The study of Yang (2013) disclosed that, when compared to men, women are negatively correlated with personal attitude, perceived behavioral control, and social norms.

Concerning social norms, and since women's role in entrepreneurial intentions is inconclusive, Liñán and Chen (2009) proposed that social norms exert their influence on entrepreneurial intentions through personal attitude and perceived behavioral control. These authors perceived a positive and noteworthy influence between male gender and personal attitude and perceived behavioral control; that is, according to their study, men are more captivated with entrepreneurial behavior and consider themselves more competent than women. Maes et al. (2014) also verified that social norms indirectly influence the entrepreneurial behavior of individuals, through a personal attitude and perceived behavioral control. The study of these authors showed that women are less attracted to an entrepreneurial career and consider themselves less suitable for entrepreneurship, concluding that the mediating role of personal attitude and perceived behavioral control factors can explain the fact that women have less entrepreneurial intentions than men.

\subsection{Entrepreneurship in Peripheral Regions}

Institutional contexts influence "entrepreneurial outcomes", as the formal and informal institutions inherent to each region influence the decisions of individuals to pursue entrepreneurial activity (Acs et al. 2008; Williams and Vorley 2014; Estrin et al. 2016; and Gherhes et al. 2018).

Formal institutions include the norms, rules, and legislation inherent to the economic activity and the legal framework of society, while informal institutions refer to the customs, principles, and values rooted in society (Acs et al. 2008; and Williams and Vorley 2014, 2017).

As Martin and Sunley (2006), Dennis (2011), and Martin (2011) mentioned, formal institutions promote entrepreneurship, resilience, and economic growth directly, while informal institutions, by highlighting "history matters" and "carriers of history", promote an "institutional hysteresis" that inhibits change and promotes "self-reproduction". The low innovation that affects peripheral regions, characterized by low dynamism, influences their economic potential, which, in turn, is determined by the low entrepreneurial potential of these regions. Asheim et al. (2011) characterized peripheral regions as having a low-level innovative activity, due to the lack of dynamic companies and knowledge-generating organizations, a "thin" and less specialized structure of knowledge providers, educational institutions, and the poorly developed networks of these providers. Leick (2020) also conducted an investigation applied to peripheral rural regions and concluded that the various agents that operate in these regions (including entrepreneurs) can promote change and provide economic development in the region.

In a study applied to the Canary Islands, in Spain, based on the theory of planned behavior and which considered motivation, opportunity, and ability theory, García-Rodríguez et al. (2017) concluded that policies to promote entrepreneurship and education programs for entrepreneurship should focus on improving entrepreneurial motivation using intensive pedagogical strategies that promote creativity, with a focus on recognizing opportunities and solving problems (problem-solving).

With a focus on peripheral places, $\mathrm{Xu}$ and Dobson (2019) tried to understand the challenges associated with the creation of entrepreneurial ecosystems in these regions, including their small size, the distance from large urban centers, and the scarcity of resources. They concluded that peripheral areas can benefit from creating their entrepreneurial ecosystem 
if a holistic collaborative approach, integrating finance, talent, socio-cultural environment, infrastructure, markets, and policies, is taken into account.

\subsection{Theoretical Model and Hypotheses}

Since the main objective of this study is to evaluate the impact of gender on entrepreneurial intention in a peripheral region of Europe, we started our approach using the existing model of Liñán and Chen (2009) on the differences in entrepreneurial intention at the level of the factors, and including the sociodemographic variable gender as performed by Maes et al. (2014). Taking into account the TPB, personal attitude, perceived behavioral control, and social norms that are used as determinants of entrepreneurial intention, we analyzed how and why these three factors arbitrate the gender impact on entrepreneurial intention, that is, how gender affects entrepreneurial intention, directly and indirectly. Considering the referred objective, the following hypotheses were formulated:

Hypothesis 1a (H1a). Being a woman has a negative impact on the personal attitude of being an entrepreneur.

Hypothesis $\mathbf{1 b} \mathbf{( H 1 b ) . ~ B e i n g ~ a ~ w o m a n ~ h a s ~ a ~ n e g a t i v e ~ i m p a c t ~ o n ~ t h e ~ p e r c e i v e d ~ b e h a v i o r a l ~ c o n t r o l ~}$ of being an entrepreneur.

Hypothesis 1c (H1c). Being a woman has a negative impact on the social norms related to entrepreneurial activity.

Hypothesis 2 (H2). Women's personal attitudes have less direct positive impact on entrepreneurial intention when compared to men's.

Hypothesis 3 (H3). Women's perceived behavioral control has less direct positive impact on entrepreneurial intent when compared to men's.

Hypothesis 4 (H4). Social norms have less direct positive impact on the personal attitude of women when compared to men's.

Hypothesis 5 (H5). Social norms have less direct positive impact on women's perceived behavioral control when compared to men's.

Hypothesis 6a (H6a). Social norms have less indirect positive impact through the personal attitude of women's entrepreneurial intention when compared to men's.

Hypothesis $\mathbf{6 b} \mathbf{( H 6 b )}$. Social norms have less indirect positive impact through perceived behavioral control of women's entrepreneurial intention when compared to men's.

The structural model and hypotheses of this research are described in Figure 1.

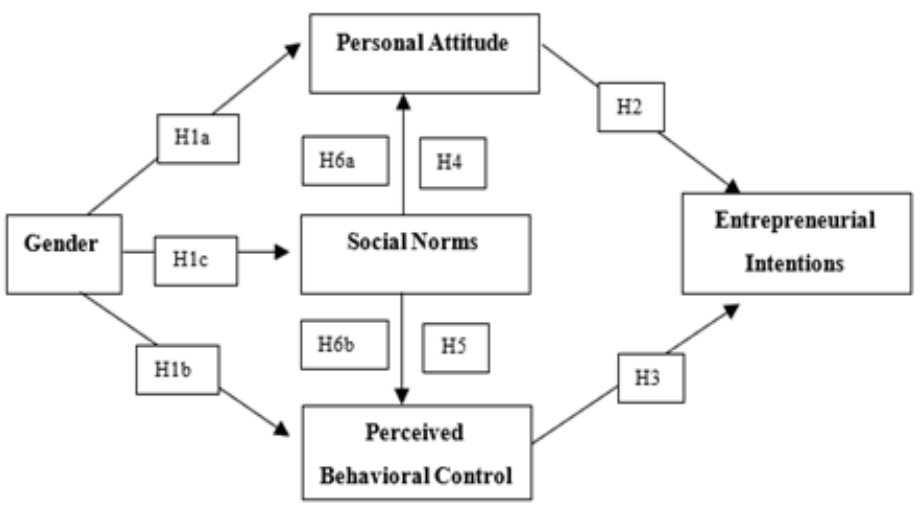

Figure 1. Structural model and hypotheses.

\section{Methodology}

This research uses a quantitative methodology, similarly to most studies on the subject of entrepreneurship, and according to the bibliometric review performed by Hlady-Rispal 
and Jouison-Laffitte (2014). This type of methodology has some advantages, such as allowing the exploration of relationships between variables, generalizing the results, and applying analysis methods and techniques to other samples, amongst others (Queirós et al. 2017).

The sample used contained 1114 observations. It was a convenience sample, which was collected through an online questionnaire on Twitter and Facebook social networks that was distributed among the population of Portugal between April 2017 and December 2020. The applied questionnaire was previously used in the study of Lopes et al. (2020b) as well as in Liñán et al. (2011). The questionnaire consisted of five groups of questions: (G1) entrepreneurial intention with four questions; (G2) perceived behavioral control with four questions; (G3) personal attitude with three questions; (G4) social norms with two questions; and (G5) sociodemographic characteristics with four questions related to age, sex, residence, and employment experience. The groups of questions G1 to G4 use a 7-point Likert scale, in which 1-I totally disagree and 7-I totally agree. The sociodemographic variable of gender took the values of 0 for men and 1 for women.

Table 1 shows the main statistics of the group of questions of sociodemographic characteristics (G5). Briefly, $65.6 \%$ of respondents were women and $34.4 \%$ were men. The average age was 26.53 years, with $76.8 \%$ of respondents being under 30 years old. They were mostly residents in mainland Portugal (83.8\%) and were studying toward or had an undergraduate degree $(67.6 \%)$. Regarding professional experience, most have had at least one professional experience $(68.9 \%)$.

Table 1. Statistics of sociodemographic characteristics.

\begin{tabular}{lccc}
\hline & Frequency & Valid Percent & Cumulative Percent \\
\hline Gender & & & \\
\hline Female & 731 & 65.6 & 65.6 \\
Male & 383 & 34.4 & 100 \\
\hline Age & & & 31.6 \\
\hline Less than 20 years & 350 & 31.6 & 76.8 \\
Between 21 and 30 years & 503 & 45.2 & 88.4 \\
Between 31 and 40 years & 129 & 11.6 & 100 \\
More than 40 years & 132 & 11.6 & \\
\hline Place of Residence & & & 93.8 \\
\hline Mainland Portugal & 934 & 83.8 & 100 \\
Azores & 100 & 9 & 31.1 \\
Madeira & 80 & 7.2 & 100 \\
\hline Job Experience & & & \\
\hline No & 347 & 31.1 & 67.6 \\
Yes & 767 & 68.9 & 100 \\
\hline Academic qualifications & & & \\
\hline Undergraduate & 753 & 67.6 & \\
Master & 254 & 9.6 & \\
Other & 107 & & \\
\hline
\end{tabular}

Concerning the groups of questions G1 to G4, the mean and standard deviation of the answers are described in Table 2.

In the entrepreneurial intention group, on average, the issues with the highest agreement amongst respondents were the commitment of all efforts to start and manage a new business (A06-4.89) and the determination to create an enterprise in the future (A134.47); in the perceived behavior control questions, the questions related to the perception of success (A14-4.64) and the perception of the ability to control the process of creating a new business (A07-4.6) were the ones that generated the highest agreement, and the 
respondents demonstrated, on average, that they have little knowledge of all the practical details to start a new business (A20-2.93).

Table 2. Mean and standard deviation of questionnaire responses.

\begin{tabular}{|c|c|c|}
\hline & Mean & Std. Deviation \\
\hline \multicolumn{3}{|l|}{ G1-Entrepreneurial Intention } \\
\hline A04.-I am ready to do anything to be an entrepreneur & 4.24 & 1.69 \\
\hline A06.-I will make every effort to start and manage my own business & 4.89 & 1.781 \\
\hline A13.-I am determined to create an enterprise in the future & 4.47 & 1.682 \\
\hline A17.-My professional objective is to be an entrepreneur & 3.75 & 1.84 \\
\hline \multicolumn{3}{|l|}{ G2-Perceived behavioral control } \\
\hline A01.--Starting a company and keeping it viable would be easy for me & 3.78 & 1.456 \\
\hline A07.- I am able to control the process of creating a new business & 4.6 & 1.518 \\
\hline A14.--If I try to start a business, I would have a high chance of being successful & 4.64 & 1.365 \\
\hline A20.-I know all about the practical details needed to start a business & 2.93 & 1.652 \\
\hline \multicolumn{3}{|l|}{ G3-Personal Attitude } \\
\hline A10.-If I had the opportunity and the resources, I would love to start a business & 5.74 & 1.581 \\
\hline A15.--Being an entrepreneur would give me great satisfaction & 5.07 & 1.712 \\
\hline A18.-Being an entrepreneur implies more advantages than disadvantages for me & 4.29 & 1.577 \\
\hline \multicolumn{3}{|l|}{ G4-Social Norms } \\
\hline C2.-The culture in my country is highly favorable to entrepreneurial activity & 3.72 & 1.556 \\
\hline C6.-In my country, entrepreneurial activity is considered valuable, despite the risks & 4.76 & 1.371 \\
\hline
\end{tabular}

In terms of personal attitude, most respondents agree that they would like to open a new business (A10-5.74), and that being an entrepreneur would give them great satisfaction (A15-5.07). In terms of social norms, the respondents showed greater agreement with the fact that entrepreneurial activity is valued in the country, despite the risks it involves (4.76).

\section{Methods of Analysis}

To test the relationships between the variables available in the structural model and the hypotheses (Figure 1), a partial least squares (PLS) model in Smart PLS 3.0 software was used (Hair et al. 2016; and Matthews et al. 2016) to perform a multigroup analysis. Multigroup analysis allows the comparison of different models between different groups that were created according to the gender of the respondents. The PLS is a variance-based method and the objective is to maximize the explained variance of endogenous latent variables (constructs), assuming the non-normal distribution of data. As the data was collected by questionnaire, there is no normality in the data. Since the PLS is a structural equation model, it is applied in two phases (McDonald and Ho 2002; and Maes et al. 2014): (1) check the adequacy of the measuring instruments, and (2) test the direct and/or indirect relationships between the latent variables.

The first step of the PLS method is to apply the PLS algorithm to the structural model, resulting in the PLS model as shown in Figure 2 for model 1. The squares represent the indicators of each latent variable and the circles represent the latent variables. Outer loadings, that is, the contribution of each indicator to explain the latent variable, are represented in the lines that make the connection between the latent variables and the indicators; according to Hair et al. (2019), they must be greater than 0.50. Inside the circles are the R-Square values. 


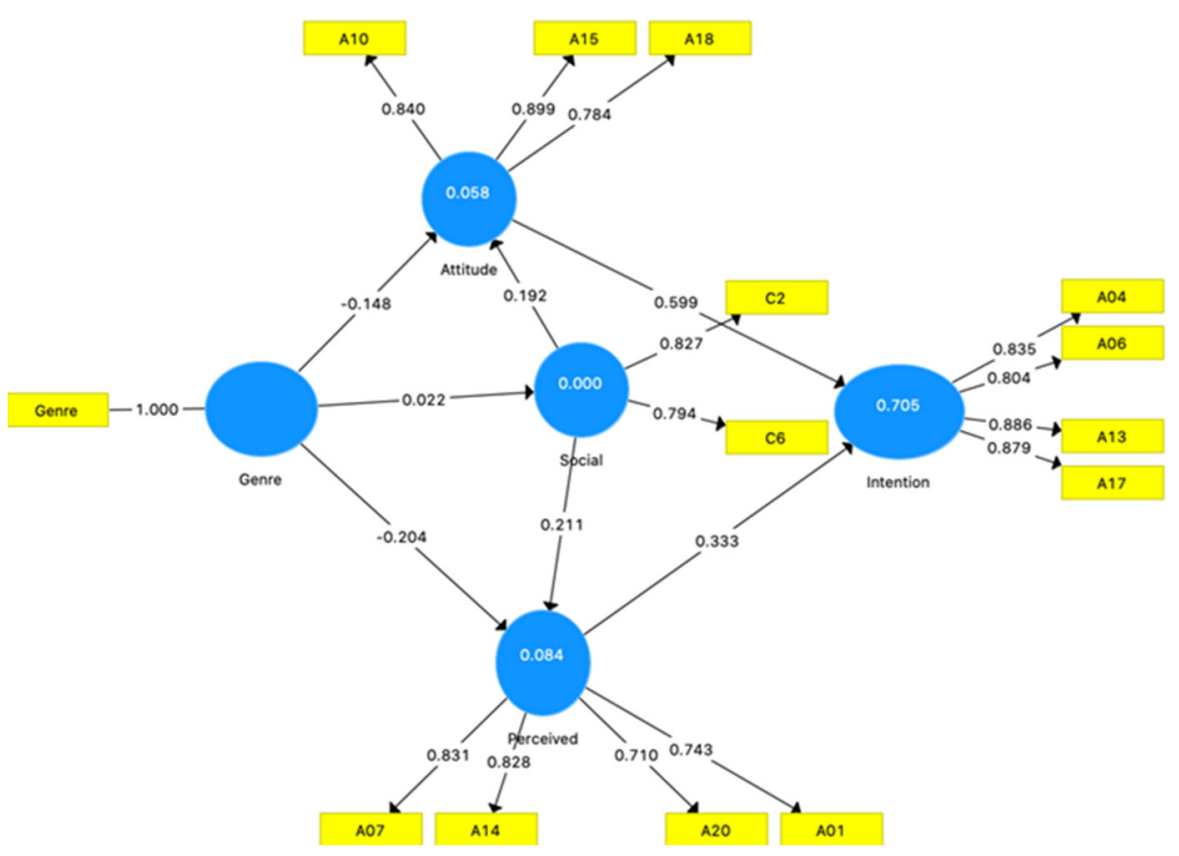

Figure 2. PLS Model for model 1 (all).

To test the adequacy of the model for the data, a confirmatory analysis was performed on the latent variables: entrepreneurial intention, personal attitude, social norms, and perceived behavioral control. Smart PLS 3.0 provides three evaluation measures of the fit model: the SRMR (standardized root mean of approximation), the NFI (normed fit index), the RMS theta (root mean squared residual covariance matrix of the outer model residuals). We started with a model (model 1) for all the observations (1114), that is, without differentiating the gender (male/female). The structural model has a good fit for data because:

(1) SRMR measures the difference between the observed correlation and the implicit correlation matrix in the model, allowing the assessment of mean discrepancies between observed and expected correlations (Hair et al. 2019) where the reference value is 0.08 (Hu and Bentler 1998). In model 1, the SRMR is 0.071 below the cut-off value (0.08).

(2) NFI results from the calculation of the $\mathrm{Chi}^{2}$ value from the proposed model and compares it with a meaningful benchmark. The value obtained must be between 0 and 1 ; model 1 has an NFI of 0.806 , being in the referred range of values.

(3) RMS theta evaluates the degree of correlation of the model's residuals, and the closer to zero, the better the model's fit. According to Henseler et al. (2014), RMS theta values below 0.12 indicate a well-fitted model, while higher values indicate a lack of fit. In model 1, the RMS theta has the value of 0.113 and, therefore, the model is considered to be adjusted.

For models 2 and 3, which refer, respectively, to the men's and women's models, the PLS algorithm was also applied to the structural model, resulting in the PLS models shown in Figures 3 and 4.

Subsequently, the same tests were performed for the group of men and women, separately. The model in which the respondents were only men, model 2 (SRMR $=0.074$; NFI: 0.802; RMS theta: 0.115), and the model in which the respondents were only women, model 3 (SRMR $=0.072$; NFI: 0.792; RMS theta: 0.115 ), proved to be good fit for the data. 


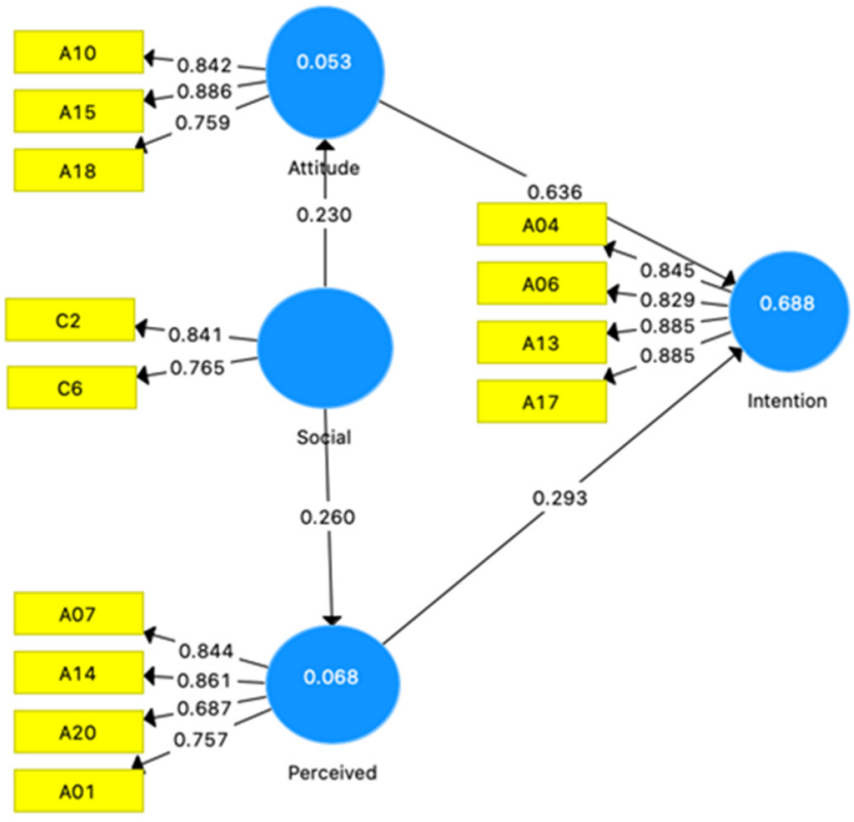

Figure 3. PLS Model for model 2 (men).

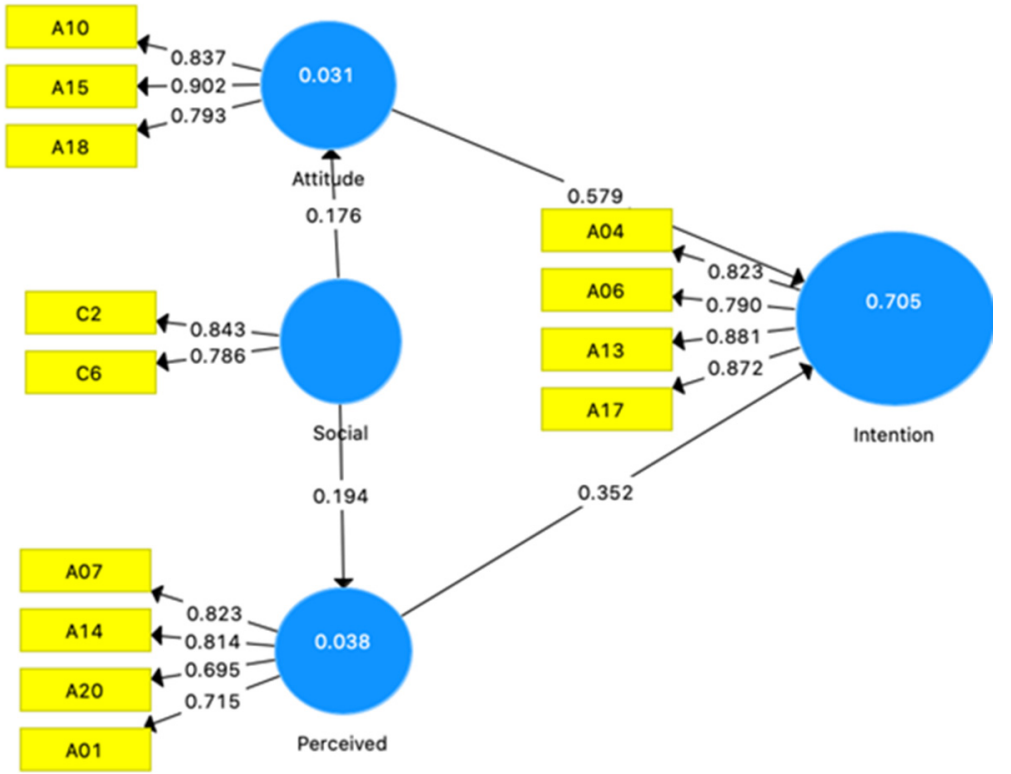

Figure 4. PLS Model for model 3 (women).

Internal consistency is evaluated by composite reliability and Cronbach's Alpha (Table 3). In all models, these indicators have values greater than 0.70 (reference values according to Hair et al. (2019)) and, as such, internal convergence is "satisfactory to good". The AVE is the sum of the square external loads of the indicators associated with the latent variables divided by the number of indicators, the reference value being 0.50. The AVEs of the latent variables in all models is greater than 0.50 , that is, on average, the latent variable explains more than half of the variance of its indicators.

To assess the discriminant validity of the model, the Fornell-Larcker criterion was used (Table 4). According to this criterion, each AVE of the latent variables (elements on the main diagonal that are in bold) must be greater than all square correlations of the latent variables (off-diagonal elements), thus establishing the discriminant validity of each of the four latent variables (Henseler et al. 2015). Once all models meet these conditions, then the model ensures the discriminant validity of the constructs. 
Table 3. Assessment of internal consistency of models.

\begin{tabular}{|c|c|c|c|c|c|c|c|c|c|c|c|c|}
\hline & \multicolumn{4}{|c|}{ Model 1-All } & \multicolumn{4}{|c|}{ Model 2-Men } & \multicolumn{4}{|c|}{ Model 3-Women } \\
\hline & Attitude & Intention & Perceived & Social & Attitude & Intention & Perceived & Social & Attitude & Intention & Perceived & Social \\
\hline $\begin{array}{c}\text { Cronbach's } \\
\text { Alpha }\end{array}$ & 0.794 & 0.873 & 0.785 & 0.779 & 0.773 & 0.884 & 0.801 & 0.755 & 0.799 & 0.863 & 0.762 & 0.797 \\
\hline $\begin{array}{l}\text { Composite } \\
\text { Reliability }\end{array}$ & 0.880 & 0.913 & 0.860 & 0.793 & 0.869 & 0.920 & 0.869 & 0.785 & 0.882 & 0.907 & 0.848 & 0.798 \\
\hline $\begin{array}{c}\text { Average } \\
\text { Variance } \\
\text { Extracted } \\
(\mathrm{AVE})\end{array}$ & 0.709 & 0.725 & 0.608 & 0.657 & 0.690 & 0.742 & 0.625 & 0.646 & 0.714 & 0.709 & 0.584 & 0.664 \\
\hline
\end{tabular}

Table 4. Discriminant validity of the model according to the Fornell-Larcker criterion.

\begin{tabular}{lcccc}
\hline & Attitude & Intention & Perceived & Social \\
\hline Model 1-All & & & & \\
\hline Attitude & $\mathbf{0 . 8 4 2}$ & & & \\
Intention & 0.775 & $\mathbf{0 . 8 5 2}$ & $\mathbf{0 . 7 8 0}$ & \\
Perceived & 0.588 & 0.686 & 0.207 & $\mathbf{0 . 8 1 1}$ \\
Social & 0.189 & 0.218 & & \\
\hline Model 2-Men & & & & \\
\hline Attitude & $\mathbf{0 . 8 3 1}$ & & $\mathbf{0 . 7 9 1}$ & \\
Intention & 0.791 & $\mathbf{0 . 8 6 1}$ & 0.260 & \\
Perceived & 0.527 & 0.628 & & \\
Social & 0.230 & 0.268 & & \\
\hline Model & & & & \\
3-Women & & & $\mathbf{0 . 7 6 4}$ & \\
\hline Attitude & $\mathbf{0 . 8 4 5}$ & 0.842 & 0.194 & \\
Intention & 0.761 & 0.701 & & \\
Perceived & 0.604 & 0.204 & & \\
Social & 0.176 & & & \\
\hline
\end{tabular}

Once the good fit, internal consistency, and discriminant validity of the models were validated, the next step was to test direct and/or indirect relationships between the latent variables, according to the structural model and the formulated hypotheses (Figure 1).

\section{Results and Discussion}

The impact of gender (male $=0$ or female $=1$ ) on the explanatory factors of the entrepreneurial intention was tested for the entire sample through model 1: personal attitude, perceived behavioral control, and social norms with the application of the PLS model obtained in Figure 2 from a bootstrap analysis (Hair et al. 2019), as shown in Figure 5.

With a statistical significance of $95 \%$ (Table 5), we conclude that gender has a negative impact $(\beta=-0.148)$ on personal attitude, meaning that being a woman has a negative influence on the attitude towards entrepreneurship, thus confirming H1a. We also conclude that gender has a negative impact $(\beta=-0.204)$ in the perceived behavioral control, that is, being a woman has a negative influence on the perceived behavior to be an entrepreneur, therefore confirming H1b. Gender is not significant to explain the social norms, although there is a positive impact of being a woman on the social norms and, therefore, H1c is rejected.

In this context, we can observe that, in this research, the findings are in line with the contributions of Fayolle et al. (2014), Liñán et al. (2011), Liñán and Chen (2009), MartínezGonzález et al. (2019), and Ruiz-Rosa et al. (2020), who found a positive relationship between the individual's attitude and entrepreneurial intention. Concerning the perceived behavioral control, the contributions of Krueger et al. (2000), Liñán and Chen (2009), Ruiz-Rosa et al. (2020), and Smith and Woodworth (2012) tell us that there is a positive relationship between perceived behavioral control and the individual's entrepreneurial 
intention. Nonetheless, the contributions of Krueger and Carsrud (1993), Lortie and Castogiovanni (2015), Ruiz-Rosa et al. (2020), and Tiwari et al. (2017) are not confirmed regarding the influence of social norms on entrepreneurial intention. These authors assume that it is sensible to anticipate a positive relationship between this variable and entrepreneurial intention, as they consider that entrepreneurs are affected by comments from people related to their closest environment on their entrepreneurial intentions. Moreover, the non-confirmation of H1c is in line with the contributions of Autio et al. (2001), Carsrud and Brännback (2011), Krueger et al. (2000), and Liñán and Chen (2009), who did not find a significant relationship between the social norms and the entrepreneurial intention of individuals.

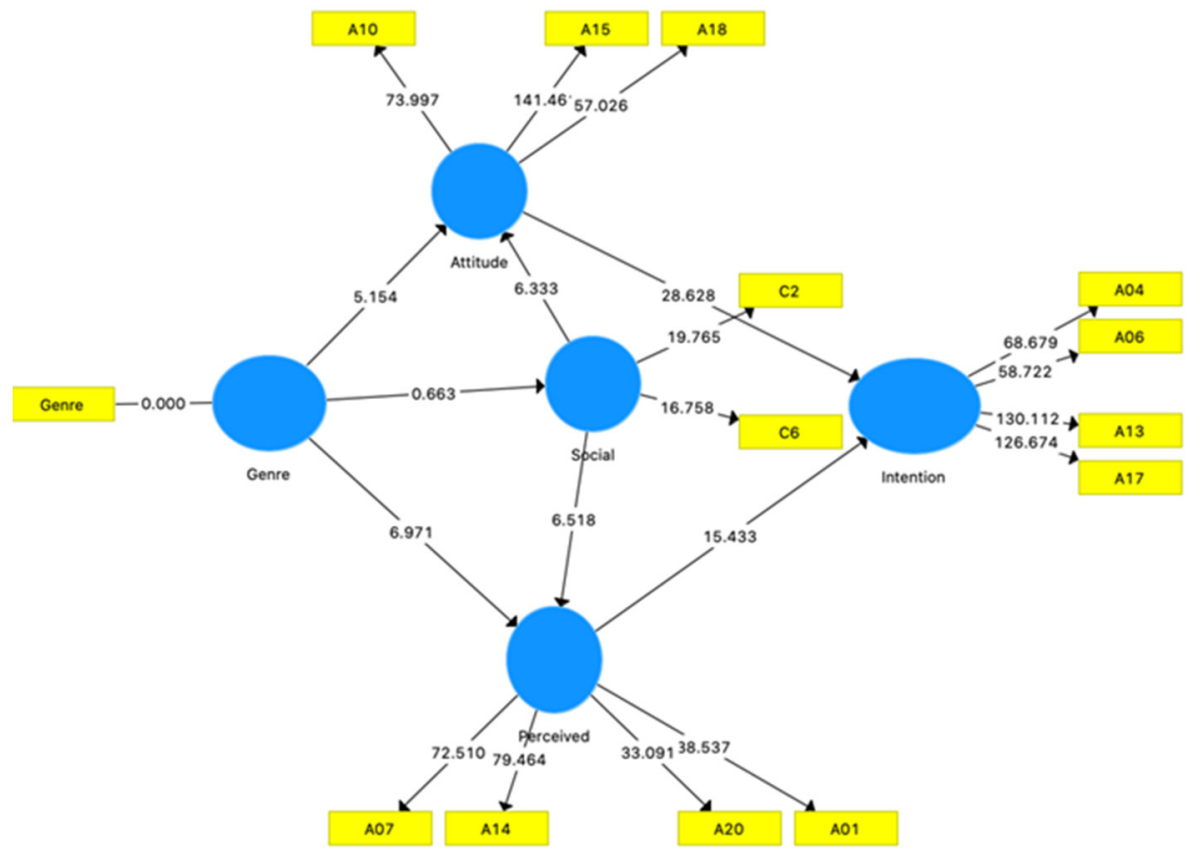

Figure 5. Bootstrap analysis to model 1 (all).

Table 5. The significance Test.

\begin{tabular}{|c|c|c|c|c|c|}
\hline & $\begin{array}{c}\text { Path Coefficients } \\
\text { Original }\end{array}$ & $\begin{array}{c}\text { Path Coefficients } \\
\text { Mean }\end{array}$ & STDEV & t-Value & $p$-Value \\
\hline \multicolumn{6}{|l|}{ Model 1-All } \\
\hline H1a: Gender -> Attitude & -0.148 & -0.148 & 0.027 & 5.512 & 0.000 * \\
\hline H1b: Gender -> Perceived & -0.204 & -0.202 & 0.029 & 6.922 & $0.000 *$ \\
\hline H1c: Gender -> Social & 0.022 & 0.021 & 0.032 & 0.675 & 0.500 \\
\hline
\end{tabular}

Note: ${ }^{*} \rho<0.01$.

Having assessed the impact of gender on the explanatory factors of entrepreneurial intention, a multigroup analysis was used to search for gender differences (male or female) in these explanatory factors. That is, we sought to understand how gender influences, through personal attitude, perceived behavioral control, and social norms, entrepreneurial intention. To achieve this, a bootstrap analysis was performed again for the structural model referring to men (model 2) and women (model 3), as shown in Figures 6 and 7. 


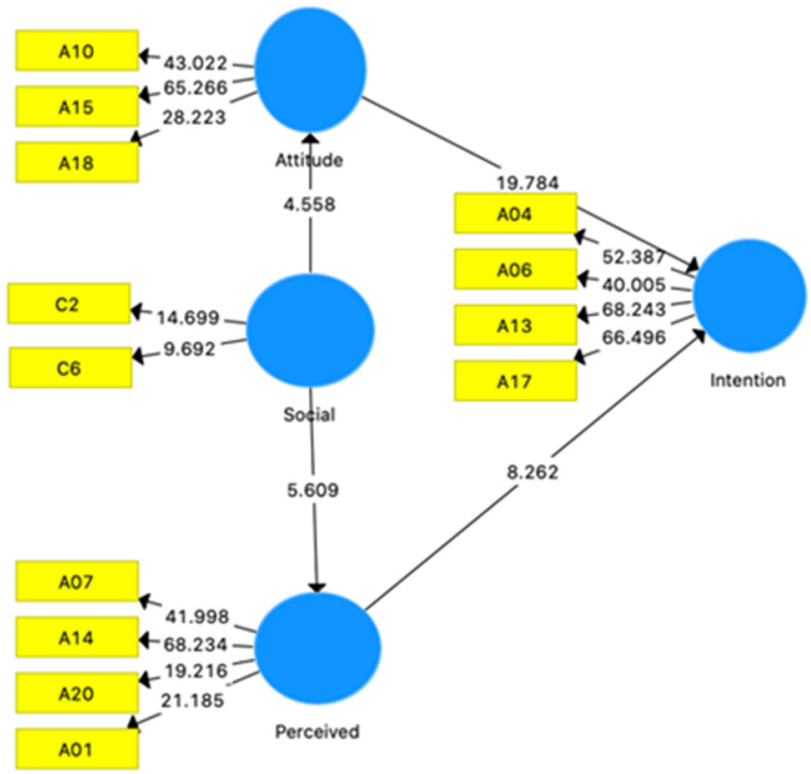

Figure 6. Bootstrap analysis to model 2 (men).

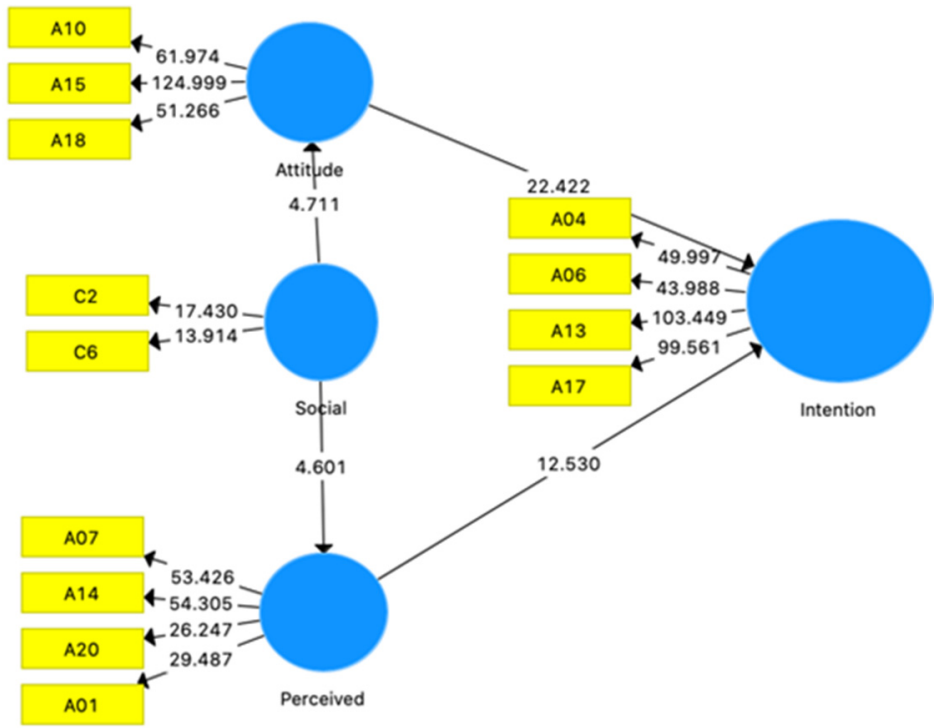

Figure 7. Bootstrap analysis to model 3 (women).

All latent variables are significant $(\rho=0.000$ ) for a statistical significance of $95 \%$, and the results are show in Table 6.

Table 6. Multigroup analysis.

\begin{tabular}{|c|c|c|c|c|c|}
\hline & $\begin{array}{c}\text { Path Coefficients } \\
\text { Original }\end{array}$ & $\begin{array}{c}\text { Path Coefficients } \\
\text { Mean }\end{array}$ & STDEV & $t$-Value & $p$-Value \\
\hline \multicolumn{6}{|l|}{ Model 2-Men } \\
\hline H2: Attitude -> Intention & 0.636 & 0.636 & 0.034 & 18.835 & 0.000 * \\
\hline H3: Perceived -> Intention & 0.293 & 0.294 & 0.035 & 8.351 & 0.000 * \\
\hline H4: Social -> Attitude & 0.230 & 0.233 & 0.049 & 4.726 & $0.000 *$ \\
\hline H5: Social -> Perceived & 0.260 & 0.262 & 0.049 & 5.327 & 0.000 * \\
\hline H6a: Social -> Attitude -> Intention & 0.146 & 0.149 & 0.033 & 4.363 & 0.000 * \\
\hline H6b: Social -> Perceived -> Intention & 0.076 & 0.077 & 0.017 & 4.482 & 0.000 * \\
\hline
\end{tabular}


Table 6. Cont.

\begin{tabular}{lcccc}
\hline & $\begin{array}{c}\text { Path Coefficients } \\
\text { Original }\end{array}$ & $\begin{array}{c}\text { Path Coefficients } \\
\text { Mean }\end{array}$ & STDEV & $t$-Value \\
\hline Model 3-Women & & & & \\
\hline H2: Attitude -> Intention & 0.579 & 0.578 & 0.026 & 21.840 \\
H3: Perceived -> Intention & 0.352 & 0.353 & 0.029 & 12.316 \\
H4: Social -> Attitude & 0.176 & 0.178 & 0.039 & 4.505 \\
H5: Social -> Perceived & 0.194 & 0.195 & 0.041 & 4.747 \\
H6a: Social -> Attitude -> Intention & 0.102 & 0.104 & $0.000^{*}$ \\
H6b: Social -> Perceived -> Intention & 0.068 & 0.069 & $0.000^{*}$ & 4.426 \\
\hline
\end{tabular}

Note: ${ }^{*} \rho<0.01$.

We can conclude that the personal attitude of women has a less direct positive impact $(\beta=0.579)$ in entrepreneurial intention when compared to men's $(\beta=0.636)$, thus confirming H2. These findings are in line with the contributions of Ferri et al. (2018) and Karimi et al. (2013), through which it is possible to verify that male individuals are driven by instrumental factors (since personal attitude is very important for men), while females are more motivated by social factors.

Women's perceived behavioral control has a direct positive impact $(\beta=0.352)$, stronger in entrepreneurial intention when compared to men's $(\beta=0.293)$, therefore rejecting $\mathrm{H} 3$. Hence, this research is in line with the contributions of Ferri et al. (2018), which tells us that the perceived behavioral control factor also has a positive effect on women's entrepreneurial intentions.

Social norms have a less direct positive impact $(\beta=0.176)$ on the personal attitude of women when compared to men's $(\beta=0.230)$, consequently confirming H4. Liñán and Chen (2009) suggest that the role of social norms influences entrepreneurial intentions through personal attitude and perceived behavioral control.

Social norms have a less direct positive impact $(\beta=0.260)$ in the perceived behavioral control of women when compared to men's $(\beta=0.194)$, therefore confirming H5. Social norms have a less positive indirect impact through personal attitude on women's entrepreneurial intention when compared to men's $(\beta=0.102$ and $\beta=0.146$, respectively), thus confirming H6a. Social norms have a less positive indirect impact through perceived behavioral control on women's entrepreneurial intention when compared to men's ( $\beta=0.068$ and $\beta=0.076$, respectively), thus confirming H6b.

The study of Maes et al. (2014) stresses that women are less tempted to follow an entrepreneurial career and consider themselves less suitable for entrepreneurship, concluding that the arbitrating role of personal attitude and perceived behavioral control factors can explain the fact that women have less entrepreneurial intentions than men, which is in line with the present research and with the confirmation of hypotheses $\mathrm{H} 4, \mathrm{H} 5$, $\mathrm{H} 6 \mathrm{a}$, and H6b. Figure 8 shows the coefficients obtained in the estimation of models 1, 2, and 3 to test each of the hypotheses, and Table 7 exhibits a summary of the hypotheses discussed in this research.

Table 7. Summary of hypotheses.

\begin{tabular}{|c|c|}
\hline Hypotheses & Supported I Not Supported \\
\hline H1a: Being a woman has a negative impact on the personal attitude of being an entrepreneur & Supported \\
\hline $\begin{array}{l}\text { H1b: Being a woman has a negative impact on the perceived behavioral control of being } \\
\text { an entrepreneur }\end{array}$ & Supported \\
\hline H1c: Being a woman has a negative impact on the social norms related to entrepreneurial activity & Not Supported \\
\hline $\begin{array}{c}\text { H2: Women's personal attitudes have less direct positive impact on entrepreneurial intention } \\
\text { when compared to men's }\end{array}$ & Supported \\
\hline
\end{tabular}


Table 7. Cont.

\begin{tabular}{|c|c|}
\hline Hypotheses & Supported I Not Supported \\
\hline $\begin{array}{c}\text { H3: Women's perceived behavioral control has less direct positive impact on their entrepreneurial } \\
\text { intent when compared to men's }\end{array}$ & Not Supported \\
\hline $\begin{array}{l}\text { H4: Social norms have less direct positive impact on the personal attitude of women when } \\
\text { compared to men's }\end{array}$ & Supported \\
\hline $\begin{array}{l}\text { H5: Social norms have a weaker direct positive impact on women's perceived behavioral control } \\
\text { when compared to men's }\end{array}$ & Supported \\
\hline $\begin{array}{l}\text { H6a: Social norms have a weaker indirect positive impact through the personal attitude on } \\
\text { women's entrepreneurial intention when compared to men's }\end{array}$ & Supported \\
\hline $\begin{array}{l}\text { H6b: Social norms have a weaker indirect positive impact through perceived behavioral control } \\
\text { on women's entrepreneurial intention when compared to men's }\end{array}$ & Supported \\
\hline
\end{tabular}

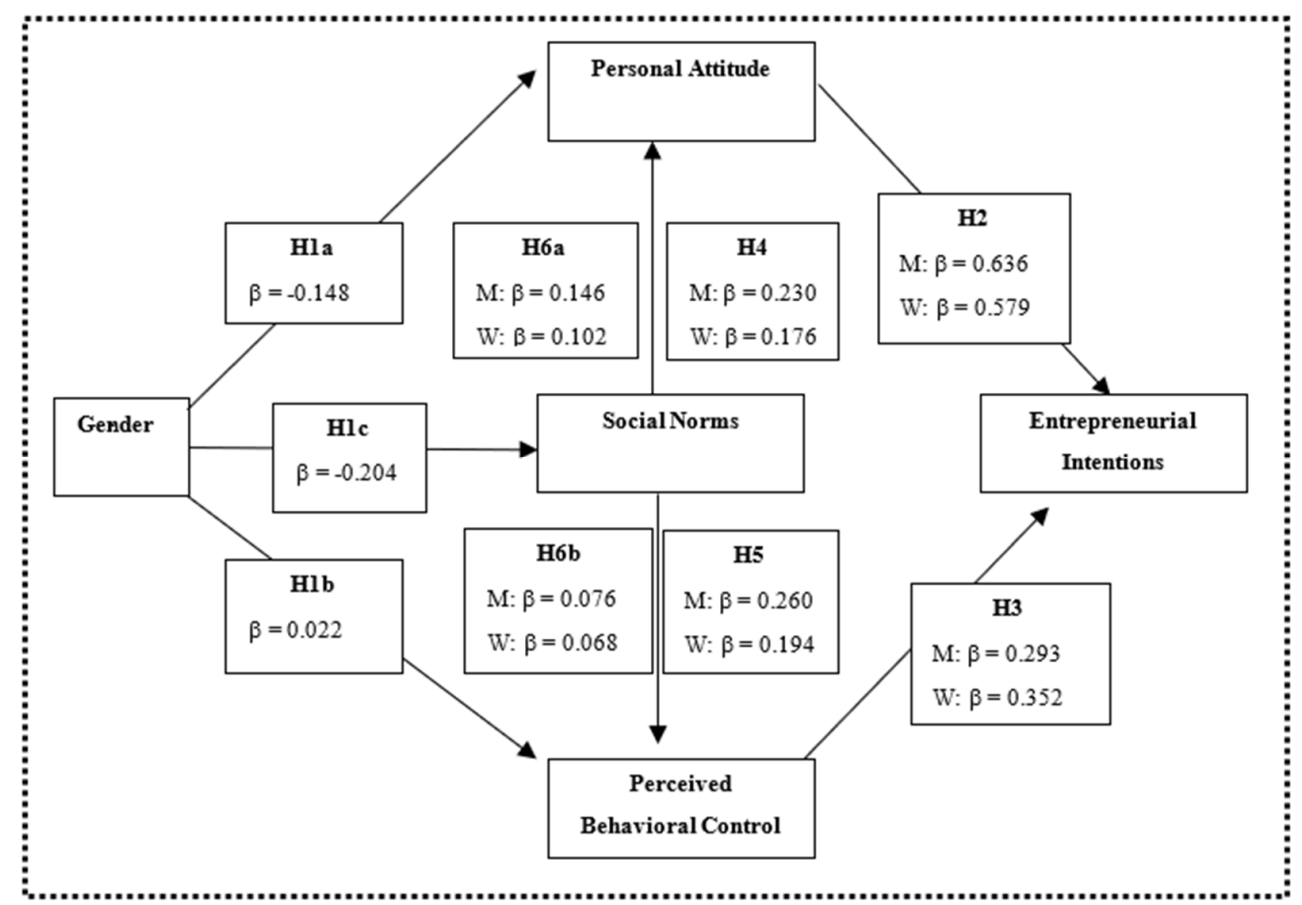

Figure 8. Summary of the coefficients obtained in the estimation of the hypotheses. Note: $\mathrm{M}=\mathrm{Men}$; $\mathrm{W}=$ Women .

\section{Conclusions}

This article assessed the impact of gender on entrepreneurial intention in a peripheral region of Europe. It was possible to conclude that women's perceived behavioral control does not have less direct positive impact on entrepreneurial intention when compared to men's; women's personal attitude has less direct positive impact on entrepreneurial intention when compared to men's; social norms have less direct positive impact on women's personal attitude when compared to men's; and social norms have less direct positive impact on women's perceived behavioral control when compared to men's. Additionally, it is also concluded that social norms have less positive indirect impact through the personal attitude and perceived behavioral control of women's entrepreneurial intention when compared to men's.

On the theoretical side, this research contributes to the reinforcement of the theoretical framework on which the studies on entrepreneurial intention of gender are based, expanding the contributions on entrepreneurial intention to peripheral regions.

Although women constitute more than half of the world's population, they own fewer businesses than men (Kim 2007), are less inclined to follow an entrepreneurial career, 
and consider themselves less suitable for entrepreneurship (Maes et al. 2014). As we already explained, there are inequalities between genders that are related to the financial inclusion of women, time availability, education gap, and other legal issues. This raises the question of reducing gender inequalities (House et al. 2021) in entrepreneurship. Does this introduce entrepreneurial opportunities to women or are they a gender barrier?

To overcome this possible barrier, and as practical contributions, our research can serve as a base for policymakers, universities, further civil society entities, and other community stakeholders to develop and strengthen the necessary conditions based on gender equality to help improve entrepreneurship amongst women. Our research serves both genders commonly when addressing entrepreneurship, for example by providing adequate legislation, access to financial resources, and market opportunities.

This paper is original as it studies a large sample with 1114 observations. It is not easy to collect so many observations in peripheral countries. The sample can be larger on the majority of studies on the subject under investigation, but it is widely recognized that studies in peripheral regions are scarce.

As for suggestions for future investigations, it would be motivating to integrate other variables in the research, in line with the relevant literature, that may influence the entrepreneurial intention of both genders and in other peripheral regions of the globe. It would also be important to compare the obtained results concerning Portugal and other peripheral countries, where entrepreneurship is more interesting and captivating, and where the rates of business creation by entrepreneurs are higher. From this analysis, it will be possible to draw inferences on the strategies and policies to be adopted in the promotion of entrepreneurship in Portugal and the creation of employment through nascent entrepreneurship, taking into account the gender factor. Another possibility for future research is to perform longitudinal research, which has the advantage of showing the indicator's evolution over time and promote chronological comparisons. It would also be pertinent and important to study entrepreneurial intention regarding sustainability in general and specifically in women.

Author Contributions: Conceptualization, J.M.L.; methodology, S.G.; software, S.G.; validation, T.S. and M.S.; formal analysis, J.O.; investigation, J.M.L., M.O., T.S., and M.S.; data curation, S.G.; writing-original draft preparation, J.M.L., S.G., J.O., T.S., M.S., and M.O.; writing-review and editing, J.O.; visualization, J.O.; supervision, J.M.L. All authors have read and agreed to the published version of the manuscript.

Funding: This work was supported by the Foundation for Science and Technology "UIDB/04630/2020".

Institutional Review Board Statement: The study was conducted according to the guidelines of the Declaration of Helsinki, and approved by the Institutional Review Board.

Informed Consent Statement: Informed consent was obtained from all subjects involved in the study.

Acknowledgments: The authors would like to thank the ISPGAYA, Polytechnic Institute of Leiria, CICS.NOVA-Interdisciplinary Center for Social Sciences, Faculty of Social and Human Sciences (FCSH/NOVA), Miguel Torga Institute of Higher Education, University of Beira Interior, NECEResearch Unit in Business Sciences, University Portucalense, and REMIT-Research on Economics, Management and Information Technologies, for their support.

Conflicts of Interest: The authors declare no conflict of interest.

\section{References}

Abdullah, Naziruddin, Noor Ul Hadi, and Léo-Paul Dana. 2018. The nexus between entrepreneur skills and successful business: A decompositional analysis. International Journal of Entrepreneurship and Small Business 34: 249-65. [CrossRef]

Acs, Zoltan J., Sameeksha Desai, and Jolanda Hessels. 2008. Entrepreneurship, economic development and institutions. Small Business Economics 31: 219-34. [CrossRef]

Adamus, Magdalena, Vladimíra Čavojová, and Jakub Šrol. 2021. The impact of stereotyped perceptions of entrepreneurship and gender-role orientation on Slovak women's entrepreneurial intentions. Gender in Management: An International Journal 36: 745-61. [CrossRef] 
Afshar Jahanshahi, Asghar, Alexander Brem, and Mohammad Shahabinezhad. 2018. Does Thinking Style Make a Difference in Environmental Perception and Orientation? Evidence from Entrepreneurs in Post-Sanction Iran. Sustainability 10: 1546. [CrossRef]

Ahsan, Mujtaba, and Stephanie A. Fernhaber. 2019. Multinational Enterprises: Leveraging a Corporate International Entrepreneurship Lens for New Insights into Subsidiary Initiatives. Journal of International Management 25: 51-65. [CrossRef]

Ajzen, Icek. 1985. From Intentions to Actions: A Theory of Planned Behavior. In Action Control: From Cognition to Behavior. Edited by Julius Kuhl and Jürgen Beckmann. Berlin/Heidelberg: Springer, pp. 11-39.

Ajzen, Icek. 1991. The theory of planned behavior. Organizational Behavior and Human Decision Processes 50: 179-211. [CrossRef]

Ajzen, Icek. 2002. Perceived Behavioral Control, Self-Efficacy, Locus of Control, and the Theory of Planned Behavior1. Journal of Applied Social Psychology 32: 665-83. [CrossRef]

Ajzen, Icek. 2012. Martin Fishbein's Legacy:The Reasoned Action Approach. The Annals of the American Academy of Political and Social Science 640: 11-27. [CrossRef]

Ajzen, Icek. 2020. The theory of planned behavior: Frequently asked questions. Human Behavior and Emerging Technologies 2: 314-24. [CrossRef]

Alvedalen, Janna, and Ron Boschma. 2017. A critical review of entrepreneurial ecosystems research: Towards a future research agenda. European Planning Studies 25: 887-903. [CrossRef]

Asheim, Bjørn T., Jerker Moodysson, and Franz Todtling. 2011. Constructing Regional Advantage: Towards State-of-the-Art Regional Innovation System Policies in Europe? European Planning Studies 19: 1133-39. [CrossRef]

Atitsogbe, Kokou A., Nambè P. Mama, Laurent Sovet, Paboussoum Pari, and Jérôme Rossier. 2019. Perceived Employability and Entrepreneurial Intentions Across University Students and Job Seekers in Togo: The Effect of Career Adaptability and Self-Efficacy. Frontiers in Psychology 10: 180. [CrossRef]

Audretsch, David B., Werner Bönte, and Prashanth Mahagaonkar. 2012. Financial signaling by innovative nascent ventures: The relevance of patents and prototypes. Research Policy 41: 1407-21. [CrossRef]

Audretsch, David B., Martin Obschonka, Samuel D. Gosling, and Jeff Potter. 2017. A new perspective on entrepreneurial regions: Linking cultural identity with latent and manifest entrepreneurship. Small Business Economics 48: 681-97. [CrossRef]

Autio, Erkko, Robert H. Keeley, Magnus Klofsten, George G. C. Parker, and Michael Hay. 2001. Entrepreneurial Intent among Students in Scandinavia and in the USA. Enterprise and Innovation Management Studies 2: 145-60. [CrossRef]

Badri, Rim, and Nejib Hachicha. 2019. Entrepreneurship education and its impact on students' intention to start up: A sample case study of students from two Tunisian universities. The International Journal of Management Education 17: 182-90. [CrossRef]

Borges, Ana Pinto, João M. Lopes, Catarina Carvalho, Bruno Miguel Vieira, and Jorge Lopes. 2021. Education as a key to provide the growth of entrepreneurial intentions. Education + Training. ahead-of-print. [CrossRef]

Campos, Francisco, Michael Frese, Markus Goldstein, Leonardo Iacovone, Hillary C. Johnson, David McKenzie, and Mona Mensmann. 2017. Teaching personal initiative beats traditional training in boosting small business in West Africa. Science 357: 1287. [CrossRef]

Carsrud, Alan, and Malin Brännback. 2011. Entrepreneurial Motivations: What Do We Still Need to Know? Journal of Small Business Management 49: 9-26. [CrossRef]

Davidsson, Per, and Benson Honig. 2003. The role of social and human capital among nascent entrepreneurs. Journal of Business Venturing 18: 301-31. [CrossRef]

Denanyoh, Richard, Kwabena Adjei, and Gabriel Effah Nyemekye. 2015. Factors that impact on entrepreneurial intention of tertiary students in Ghana. International Journal of Business and Social Research 5: 19-29.

Dennis, William J. 2011. Entrepreneurship, Small Business and Public Policy Levers. Journal of Small Business Management 49: 92-106. [CrossRef]

Enkel, Ellen, and Karoline Bader. 2016. Why do experts contribute in cross-industry innovation? A structural model of motivational factors, intention and behavior. RED Management 46: 207-26. [CrossRef]

Esfandiar, Kourosh, Mohamad Sharifi-Tehrani, Stephen Pratt, and Levent Altinay. 2019. Understanding entrepreneurial intentions: A developed integrated structural model approach. Journal of Business Research 94: 172-82. [CrossRef]

Estrin, Saul, Tomasz Mickiewicz, and Ute Stephan. 2016. Human capital in social and commercial entrepreneurship. Journal of Business Venturing 31: 449-67. [CrossRef]

Farrukh, Muhammad, Yazan Alzubi, Imran Ahmad Shahzad, Abdul Waheed, and Nagina Kanwal. 2018. Entrepreneurial intentions. Asia Pacific Journal of Innovation and Entrepreneurship 12: 399-414. [CrossRef]

Fayolle, Alain, and Francisco Liñán. 2014. The future of research on entrepreneurial intentions. Journal of Business Research 67: 663-66. [CrossRef]

Fayolle, Alain, Francisco Liñán, and Juan A. Moriano. 2014. Beyond entrepreneurial intentions: Values and motivations in entrepreneurship. International Entrepreneurship and Management Journal 10: 679-89. [CrossRef]

Ferri, Luca, Gianluca Ginesti, Rosanna Spanò, and Annamaria Zampella. 2018. Exploring the Entrepreneurial Intention of Female Students in Italy. Journal of Open Innovation: Technology, Market, and Complexity 4: 27. [CrossRef]

Fuller, Bryan, Yan Liu, Saleh Bajaba, Laura E. Marler, and Jon Pratt. 2018. Examining how the personality, self-efficacy, and anticipatory cognitions of potential entrepreneurs shape their entrepreneurial intentions. Personality and Individual Differences 125: 120-25. [CrossRef]

García-Rodríguez, Francisco J., Esperanza Gil-Soto, Inés Ruiz-Rosa, and Desiderio Gutiérrez-Taño. 2017. Entrepreneurial process in peripheral regions: The role of motivation and culture. European Planning Studies 25: 2037-56. [CrossRef] 
Gherhes, Cristian, Tim Vorley, and Nick Williams. 2018. Entrepreneurship and local economic resilience: The impact of institutional hysteresis in peripheral places. Small Business Economics 51: 577-90. [CrossRef]

Gomes, Sofia, Marlene Sousa, Tânia Santos, José Oliveira, Márcio Oliveira, and João M. Lopes. 2021. Opening the "Black Box" of University Entrepreneurial Intention in the Era of the COVID-19 Pandemic. Social Sciences 10: 181. [CrossRef]

Gurel, Eda, Levent Altinay, and Roberto Daniele. 2010. Tourism students' entrepreneurial intentions. Annals of Tourism Research 37: 646-69. [CrossRef]

Hair, Joe F., Jr., Marko Sarstedt, Lucy M. Matthews, and Christian M. Ringle. 2016. Identifying and treating unobserved heterogeneity with FIMIX-PLS: Part I-Method. European Business Review 28: 63-76. [CrossRef]

Hair, Joseph F., Jeffrey J. Risher, Marko Sarstedt, and Christian M. Ringle. 2019. When to use and how to report the results of PLS-SEM. European Business Review 31: 2-24. [CrossRef]

Henseler, Jörg, Theo K. Dijkstra, Marko Sarstedt, Christian M. Ringle, Adamantios Diamantopoulos, Detmar W. Straub, David J. Ketchen, Joseph F. Hair, G. Tomas M. Hult, and Roger J. Calantone. 2014. Common Beliefs and Reality about PLS. Organizational Research Methods 17: 182-209. [CrossRef]

Henseler, Jörg, Christian M. Ringle, and Marko Sarstedt. 2015. A new criterion for assessing discriminant validity in variance-based structural equation modeling. Journal of the Academy of Marketing Science 43: 115-35. [CrossRef]

Hindle, Kevin, Kim Klyver, and Daniel F. Jennings. 2009. An 'Informed' Intent Model: Incorporating Human Capital, Social Capital, and Gender Variables into the Theoretical Model of Entrepreneurial Intentions. In Understanding the Entrepreneurial Mind: Opening the Black Box. Edited by Alan L. Carsrud and Malin Brännback. New York: Springer, pp. 35-50.

Hlady-Rispal, Martine, and Estèle Jouison-Laffitte. 2014. Qualitative research methods and epistemological frameworks: A review of publication trends in entrepreneurship. Journal of Small Business Management 52: 594-614. [CrossRef]

House, Allan, Naila Dracup, Paula Burkinshaw, Vicky Ward, and Louise D. Bryant. 2021. Mentoring as an intervention to promote gender equality in academic medicine: A systematic review. BMJ Open 11: e040355. [CrossRef]

$\mathrm{Hu}$, Li-tze, and Peter M. Bentler. 1998. Fit indices in covariance structure modeling: Sensitivity to underparameterized model misspecification. Psychological Methods 3: 424. [CrossRef]

Karimi, Saeid, Harm J. A. Biemans, Thomas Lans, Mohammad Chizari, Martin Mulder, and Karim Naderi Mahdei. 2013. Understanding role Models and Gender Influences on Entrepreneurial Intentions among College Students. Procedia Social and Behavioral Sciences 93: 204-14. [CrossRef]

Karimi, Saeid, Harm J. A. Biemans, Thomas Lans, Mohammad Chizari, and Martin Mulder. 2016. The Impact of Entrepreneurship Education: A Study of Iranian Students' Entrepreneurial Intentions and Opportunity Identification. Journal of Small Business Management 54: 187-209. [CrossRef]

Kim, GiSeung. 2007. The analysis of self-employment levels over the life-cycle. The Quarterly Review of Economics and Finance 47: 397-410. [CrossRef]

Krueger, Norris. 2020. Entrepreneurial potential and potential entrepreneurs: 25 years on. Journal of the International Council for Small Business 1: 52-55. [CrossRef]

Krueger, Norris F., and Deborah V. Brazeal. 1994. Entrepreneurial Potential and Potential Entrepreneurs. Entrepreneurship Theory and Practice 18: 91-104. [CrossRef]

Krueger, Norris F., and Alan L. Carsrud. 1993. Entrepreneurial intentions: Applying the theory of planned behaviour. Entrepreneurship $\mathcal{E}$ Regional Development 5: 315-30. [CrossRef]

Krueger, Norris F., Jr., Michael D. Reilly, and Alan L. Carsrud. 2000. Competing models of entrepreneurial intentions. Journal of Business Venturing 15: 411-32. [CrossRef]

Lanahan, Lauren, and Maryann P. Feldman. 2015. Multilevel innovation policy mix: A closer look at state policies that augment the federal SBIR program. Research Policy 44: 1387-402. [CrossRef]

Lee, Soo Hoon, and Poh Kam Wong. 2004. An exploratory study of technopreneurial intentions: A career anchor perspective. Journal of Business Venturing 19: 7-28. [CrossRef]

Leick, Birgit. 2020. Institutional entrepreneurs as change agents in rural-peripheral regions. ISR-Forsch 49: 22-35.

Lewandowska, Anna, Mateusz Stopa, and Elżbieta Inglot-Brzęk. 2021. Innovativeness and entrepreneurship: Socioeconomic remarks on regional development in peripheral regions. Economics $\mathcal{E}$ Sociology 14: 222-35. [CrossRef]

Liñán, Francisco, and Yi-Wen Chen. 2009. Development and cross-cultural application of a specific instrument to measure entrepreneurial intentions. Entrepreneurship: Theory and Practice 33: 593-617. [CrossRef]

Liñán, Francisco, David Urbano, and Maribel Guerrero. 2011. Regional variations in entrepreneurial cognitions: Start-up intentions of university students in Spain. Entrepreneurship \& Regional Development 23: 187-215. [CrossRef]

Linan, Francisco, Isidoro Romero Luna, and José Fernández Serrano. 2013. Necessity and Opportunity Entrepreneurship: The Mediating Effect of Culture. Revista De Economia Mundial 11: 21-47.

Lopes, João, Helder Antunes, and Ricardo Rodrigues. 2018. Comparative Entrepreneurship between Western Europe and Latin America. Entrepreneurship Research Journal 8. [CrossRef]

Lopes, João, João J. Ferreira, Luís Farinha, and Mário Raposo. 2020a. Emerging Perspectives on Regional Academic Entrepreneurship. Higher Education Policy 33: 367-95. [CrossRef]

Lopes, João, Sergio Jesus Teixeira, João J. M. Ferreira, Paulo Silveira, Luís Farinha, and João Lussuamo. 2020b. University entrepreneurial intentions: Mainland and insular regions-Are they different? Education + Training 62: 81-99. [CrossRef] 
Lopes, João, João J. Ferreira, and Luís Farinha. 2021a. Entrepreneurship and the resource-based view: What is the linkage? A bibliometric approach. International Journal of Entrepreneurial Venturing 13: 137-64. [CrossRef]

Lopes, João M., Sofia Gomes, Tânia Santos, Márcio Oliveira, and José Oliveira. 2021b. Entrepreneurial Intention before and during COVID-19-A Case Study on Portuguese University Students. Education Sciences 11: 273. [CrossRef]

Lortie, Jason, and Gary Castogiovanni. 2015. The theory of planned behavior in entrepreneurship research: What we know and future directions. International Entrepreneurship and Management Journal 11: 935-57. [CrossRef]

Lortie, Jason, Gary J. Castrogiovanni, and Kevin C. Cox. 2017. Gender, social salience, and social performance: How women pursue and perform in social ventures. Entrepreneurship \& Regional Development 29: 155-73. [CrossRef]

Maes, Johan, Hannes Leroy, and Luc Sels. 2014. Gender differences in entrepreneurial intentions: A TPB multi-group analysis at factor and indicator level. European Management Journal 32: 784-94. [CrossRef]

Martin, Ron. 2011. Regional economic resilience, hysteresis and recessionary shocks. Journal of Economic Geography 12: 1-32. [CrossRef]

Martin, Ron, and Peter Sunley. 2006. Path dependence and regional economic evolution. Journal of Economic Geography 6: 395-437. [CrossRef]

Martínez-González, José A., Urszula Kobylinska, Francisco J. García-Rodríguez, and Lukasz Nazarko. 2019. Antecedents of Entrepreneurial Intention among Young People: Model and Regional Evidence. Sustainability 11: 6993. [CrossRef]

Matthews, Lucy M., Marko Sarstedt, Joseph F. Hair, and Christian M. Ringle. 2016. Identifying and treating unobserved heterogeneity with FIMIX-PLS: Part II-A case study. European Business Review 28: 208-24. [CrossRef]

McDonald, Roderick P., and Moon-Ho Ringo Ho. 2002. Principles and practice in reporting structural equation analyses. Psychological Methods 7: 64. [CrossRef]

Mei, Hu, Zehui Zhan, Patrick S. W. Fong, Ting Liang, and Zicheng Ma. 2016. Planned behaviour of tourism students' entrepreneurial intentions in China. Applied Economics 48: 1240-54. [CrossRef]

Miranda, F. Javier, Antonio Chamorro-Mera, Sergio Rubio, and Jesús Pérez-Mayo. 2017. Academic entrepreneurial intention: The role of gender. International Journal of Gender and Entrepreneurship 9: 66-86. [CrossRef]

Molino, Monica, Valentina Dolce, Claudio Giovanni Cortese, and Chiara Ghislieri. 2018. Personality and social support as determinants of entrepreneurial intention. Gender differences in Italy. PLoS ONE 13: e0199924. [CrossRef] [PubMed]

Nabi, Ghulam, and Rick Holden. 2008. Graduate entrepreneurship: Intentions, education and training. Education + Training 50: 545-51. [CrossRef]

Queirós, André, Daniel Faria, and Fernando Almeida. 2017. Strengths and limitations of qualitative and quantitative research methods. European Journal of Education Studies. [CrossRef]

Ridha, Rizki Novanda, Burhanuddin, and Budi Priyatna Wahyu. 2017. Entrepreneurship intention in agricultural sector of young generation in Indonesia. Asia Pacific Journal of Innovation and Entrepreneurship 11: 76-89. [CrossRef]

Rubio-Bañón, Alicia, and Nuria Esteban-Lloret. 2016. Cultural factors and gender role in female entrepreneurship. Suma de Negocios 7: 9-17. [CrossRef]

Ruiz-Rosa, Inés, Desiderio Gutiérrez-Taño, and Francisco J. García-Rodríguez. 2020. Social Entrepreneurial Intention and the Impact of COVID-19 Pandemic: A Structural Model. Sustainability 12: 6970. [CrossRef]

Salavou, Helen Efstratios, Georgios Chalkos, and Spyros Lioukas. 2021. Linkages between entrepreneurial intentions and entrepreneurship education: New evidence on the gender imbalance. Education + Training 63: 906-19. [CrossRef]

Schlaegel, Christopher, and Michael Koenig. 2014. Determinants of Entrepreneurial Intent: A Meta-Analytic Test and Integration of Competing Models. Entrepreneurship Theory and Practice 38: 291-332. [CrossRef]

Scott, W. Richard. 2008. Approaching adulthood: The maturing of institutional theory. Theory and Society 37: 427. [CrossRef]

Shinnar, Rachel S., Olivier Giacomin, and Frank Janssen. 2012. Entrepreneurial Perceptions and Intentions: The Role of Gender and Culture. Entrepreneurship Theory and Practice 36: 465-93. [CrossRef]

Shirokova, Galina, Oleksiy Osiyevskyy, and Karina Bogatyreva. 2016. Exploring the intention-behavior link in student entrepreneurship: Moderating effects of individual and environmental characteristics. European Management Journal 34: 386-99. [CrossRef]

Smith, Isaac H., and Warner P. Woodworth. 2012. Developing Social Entrepreneurs and Social Innovators: A Social Identity and Self-Efficacy Approach. Academy of Management Learning E Education 11: 390-407. [CrossRef]

Stam, Erik. 2015. Entrepreneurial Ecosystems and Regional Policy: A Sympathetic Critique. European Planning Studies 23: 1759-69. [CrossRef]

Thompson, Edmund R. 2009. Individual Entrepreneurial Intent: Construct Clarification and Development of an Internationally Reliable Metric. Entrepreneurship Theory and Practice 33: 669-94. [CrossRef]

Tiwari, Preeti, Anil K. Bhat, and Jyoti Tikoria. 2017. An empirical analysis of the factors affecting social entrepreneurial intentions. Journal of Global Entrepreneurship Research 7: 9. [CrossRef]

Trettin, Lutz, and Friederike Welter. 2011. Challenges for spatially oriented entrepreneurship research. Entrepreneurship \& Regional Development 23: 575-602. [CrossRef]

Urbano, David, Sebastian Aparicio, and David Audretsch. 2019. Twenty-five years of research on institutions, entrepreneurship, and economic growth: What has been learned? Small Business Economics 53: 21-49. [CrossRef]

Vamvaka, Vasiliki, Chrysostomos Stoforos, Theodosios Palaskas, and Charalampos Botsaris. 2020. Attitude toward entrepreneurship, perceived behavioral control, and entrepreneurial intention: Dimensionality, structural relationships, and gender differences. Journal of Innovation and Entrepreneurship 9: 5. [CrossRef] 
Veciana, José Ma, Marinés Aponte, and David Urbano. 2005. University Students' Attitudes towards Entrepreneurship: A Two Countries Comparison. The International Entrepreneurship and Management Journal 1: 165-82. [CrossRef]

Vracheva, Veselina, and Irina Stoyneva. 2020. Does gender equality bridge or buffer the entrepreneurship gender gap? A cross-country investigation. International Journal of Entrepreneurial Behavior \& Research 26: 1827-44. [CrossRef]

Wang, Clement K., and Poh-Kam Wong. 2004. Entrepreneurial interest of university students in Singapore. Technovation $24: 163-72$. [CrossRef]

Westhead, Paul, and Marina Z. Solesvik. 2016. Entrepreneurship education and entrepreneurial intention: Do female students benefit? International Small Business Journal 34: 979-1003. [CrossRef]

Williams, Nick, and Tim Vorley. 2014. Institutional asymmetry: How formal and informal institutions affect entrepreneurship in Bulgaria. International Small Business Journal 33: 840-61. [CrossRef]

Williams, Nick, and Tim Vorley. 2017. Creating institutional alignment and fostering productive entrepreneurship in new born states. Entrepreneurship and Regional Development 29: 444-46. [CrossRef]

Worldometer. 2021. Portugal Population. Worldometer. Available online: https://www.worldometers.info/world-population/ portugal-population/ (accessed on 13 October 2021).

Xu, Zimu, and Stephen Dobson. 2019. Challenges of building entrepreneurial ecosystems in peripheral places. Journal of Entrepreneurship and Public Policy 8: 408-30. [CrossRef]

Yan, Xiaohan, Dongxiao Gu, Changyong Liang, Shuping Zhao, and Wenxing Lu. 2018. Fostering Sustainable Entrepreneurs: Evidence from China College Students' “Internet Plus" Innovation and Entrepreneurship Competition (CSIPC). Sustainability 10: 3335. [CrossRef]

Yang, Jianfeng. 2013. The theory of planned behavior and prediction of entrepreneurial intention among Chinese undergraduates. Social Behavior and Personality: An International Journal 41: 367-76. [CrossRef]

Yıldırım, Nihan, Özgür Çakır, and Olcay Bige Aşkun. 2016. Ready to Dare? A Case Study on the Entrepreneurial Intentions of Business and Engineering Students in Turkey. Procedia-Social and Behavioral Sciences 229: 277-88. [CrossRef]

Zampetakis, Leonidas A., Maria Bakatsaki, Charalambos Litos, Konstantinos G. Kafetsios, and Vassilis Moustakis. 2017. Gender-based Differential Item Functioning in the Application of the Theory of Planned Behavior for the Study of Entrepreneurial Intentions. Frontiers in Psychology 8: 451. [CrossRef] [PubMed]

Zhao, Hao, Scott E. Seibert, and Gerald E. Hills. 2005. The mediating role of self-efficacy in the development of entrepreneurial intentions. Journal of Applied Psychology 90: 1265. [CrossRef] 